\title{
PERAN PENDIDIKAN AGAMA HINDU DALAM MEMBENTUK KEPRIBADIAN SISWA
}

\author{
Oleh \\ Ni Kadek Santya Pratiwi \\ Yayasan Pengembangan Anak Indonesia \\ Email:kyoo84@yahoo.com
}

\begin{abstract}
ABSTRAK
Pembentukan karakter pada anak merupakan suatu upaya yang berkesinambungan dengan dasar yang kuat. Dasar yang dimaksud merujuk pada nilai-nilai yang dikembangkan di lingkungan tempat anak tumbuh dan berkembang. Nilai-nilai luhur yang berkembang bersumber dari nilainilai ajaran agama yang dianut para peserta didik. Khususnya di Bali dengan mayoritas pendduk beragama Hindu, Pendidikan agama memiliki konstribusi besar dalam pembentukan karakter anak.
\end{abstract}

Kata Kunci : Peran pendidikan Agama, Karakter Siswa

\section{ABSTRACT}

Children's character building is a continuous effort with a strong foundation. The basis in question refers to the values developed in the environment where children grow and develop. The noble values that develop are derived from the values of religious teachings adopted by the students. Especially in Bali with the majority of Hindus, religious education has a major contribution to the formation of children's character.

Keywords: The role of religious education, student character

\section{PENDAHULUAN}

Salah satu permasalahan yang dihadapi oleh bangsa Indonesia dalam dunia pendidikan adalah rendahnya mutu pendidikan pada setiap jenjang dan satuan pendidikan serta merosotnya moral etika para siswa. Hal ini telah tidak bisa dikaji hanya dengan melihat satu aspek saja. Kondisi sosial ekonomi serta keadaan pendidikan kita dilapangan mengalami sebuah gejala kesenjangan. Banyaknya bangunan sekolah yang tidak layak pakai untuk melakukan proses pembelajaran, biaya pendidikan yang mahal, yang sulit dijangkau bagi kebanyakan masyarakat. Dan bahkan banyak anak-anak kecil yang putus sekolah dan memutuskan untuk mencari uang meski dengan harus turun ke jalanan karena mereka tidak mampu membayar biaya pendidikan yang begitu tinggi terutama di perkotaan. Kurikulum yang selalu berubah mempengaruhi seluruh aspek dan komponen dalam proses belajarmengajar tersebut. Pendidikan seakan-akan dijadikan kelinci percobaan dan terlihat ada suatu unsur komersil dalam setiap perubahan yang terjadi dalam pendidikan. Dari kalangan pemerintah selalu menginginkan kenaikan mutu pendidikan. Akan tetapi mereka tidak pernah menyesuaikan dan membandingkan antara tuntutan keinginan yang begitu tinggi dengan kondisi yang real terjadi di lapangan.

Bila keadaannya seperti ini, akan sangat sulit untuk menciptakan dunia pendidikan yang baik, dimana proses transformasi 
ilmu terjadi. Dan bahkan bila diamati lebih dalam, dari faktor-faktor yang menyebabkan rendahnya mutu pendidikan di indonesia, akan menimbulkan suatu krisis karakteristik positif dan terjadinya degradasi moral dikalangan pelajar. Bagaimana tidak, dengan mahalnya biaya pendidikan, para tunas bangsa tidak bisa melanjutkan pendidikan ke jenjang yang lebih tinggi dan bahkan putus sekolah. Dalam kondisi seperti ini, dengan pendidikan moral, etika dan budi pekerti yang minim mereka dapatkan disertai kondisi ekonomi yang selalu menjerat leher mereka, muncullah benih-benih karakter negatif yang cenderung mengindikasikan sesuatu yang bersifat kriminal. Tentu hal ini tidak pernah kita harapkan akan terjadi pada generasi penerus bangsa .

Bagaimanakah sebuah bangsa bisa maju kalau generasi muda mereka memiliki karakter yang tidak baik? Fenomena terdegradasinya moral suatu bangsa memang sangat mengkhawatirkan. Disinilah seharusnya pendidikan mampu berperan aktif. Pendidikan yang baik adalah pendidikan yang bisa membentuk karakter positif kepada peserta didik. Pendidikan agama adalah salah satu usaha konkret yang bisa diterapkan baik secara formal maupun non formal untuk mengatasi degradasi moral dan krisis karakter positif tersebut. Semua agama mengajarkan hal yang baik. Tapi ada oknum-oknum tertentu yang menyalahgunakan agama sebagai tameng untuk membenarkan perbuatan yang tidak benar. Disini akan dijelaskan tentang pendidikan agama khususnya agama Hindu seberapa besarkah kontribusi pendidikan agama Hindu dalam membentuk karakter siswa yang beragama Hindu.

Pendidikan agama dalam sistem pendidikan nasional tampaknya terdapat konsistensi dan keterkaitan langsung antara rumusan fungsi pendidikan agama dengan tujuan pendidikan nasional yang tertuang pada pasal 3 UU RI Nomor 20 tahun 2003 yaitu : "Pendidikan nasional berfungsi mengembangkan kemampuan dan membentuk watak serta peradaban bangsa yang bermartabat dalam rangka mencerdaskan kehidupan bangsa, bertujuan untuk berkembangnya potensi peserta didik agar menjadi manusia yang beriman dan bertaqwa kepada Tuhan Yang Maha Esa, berakhlak mulia, sehat, berilmu, cakap, kreatif, mandiri, dan menjadi warga Negara yang demokratis serta bertanggung jawab. (Sisdiknas, 2003 :6) Dalam upaya membentuk manusia Indonesia yang beriman dan bertakwa, maka pendidikan agama memiliki peranan yang sangat penting. Untuk itulah maka pendidikan agama wajib diberikan pada semua satuan, jenjang dan jenis pendidikan, baik melalui jalur sekolah maupun jalur luar sekoah. (Hasbullah, 1999 : 177).

Agama Hindu adalah agama yang universal yang mengajarkan kepada umat manusia mengenai berbagai aspek kehidupan, baik duniawi maupun akhirat. Salah satu diantara ajaran Hindu tersebut adalah mewajibkan kepada umat Hindu untuk melaksanakan pendidikan, karena menurut ajaran Hindu pendidikan adalah juga merupakan kebutuhan hidup manusia yang mutlak harus dipenuhi, demi untuk mencapai kesejahteraan dan kebahagiaan dunia dan akhirat. Dengan pendidikan itu pula manusia akan mendapatkan berbagai macam ilmu pengetahuan untuk bekal dan kehidupannya.

Tentang bagaimana jiwa dan kepribadian seorang anak serta bagaimana perkembangan selanjutnya, semua tergantung bagaimana cara kita memberikan pendidikan utamanya pendidikan agama sebagai modal kepribadian. Fitrah beragama pada manusia telah dibawa sejak lahirnya, maka fitrah tersebut akan berkembang dengan adanya pendidikan. Karena adanya fitrah beragama itu maka manusia disebut homo dinivans (makhluk berketuhanan) atau juga disebut sebagai homo religius (makhluk beragama), karena dengan 
adanya agama manusia akan mendapatkan ketentraman lahir dan batin.

\section{PEMBAHASAN}

\section{A. Pengertian Pendidikan Agama Hindu}

Kata education 'pendidikan' berasal dari akar kata bahasa latin 'educare', menunjukkan pengumpulan berbagai fakta duniawi, maka educare merupakan usaha untuk menampilkan apa yang laten di dalam diri manusia. Pendidikan digunakan untuk penghidupan, sedangkan, educare digunakan untuk hidup. Pendidikan digunakan untuk mencari nafkah (Jivanopadhi), educare digunakan untuk mencapai tujuan akhir kehidupan (Jivitha paramavadhi).

Menurut The Encyclopedia American pengertian pendidikan yakni suatu proses seseorang mendapatkan pengetahuan, pemahaman, mengembangkan sikap-sikap atau keterampilan-keterampilan. Pendidikan mempunyai dua fungsi:

1. Fungsi Sosial, pendidikan bertugas untuk menolong setiap individu agar dapat menjadi anggota masyarakat yang berhasil guna dengan cara mengajarkan kepadanya sejumlah pengalaman masa lalu dan pengalaman masa kini.

2. Fungsi lndividu, pendidikan bertugas menolong dan membina individu agar dapat menikmati kehidupan yang lebih baik, lebih memuaskan dan lebih berhasil dengan cara mempersiapkan individu tersebut untuk menangani pengalaman-pengalaman baru dengan baik

Pendidikan tidak semata-mata bertujuan hanya untuk mengajar mata pelajaran, tetapi mendidik, membesarkan dan mengembangkan kepribadian anak. Pendidikan adalah perwujudan kesempurnaan yang telah ada pada dirimanusia. Jadi ia merupakan pengembangan yang terpadu dan harmonis pada kepribadian manusia. Pendidikan yang dimaksudkan adalah menggali potensi-potensi kepribadian yang secara kodrati telah berada dalam diri manusia. Pendidikan seumur hidup bukan untuk sekedar hidup. Pendidikan semestinya merupakan proses perkembangan kepribadian manusia secara menyeluruh, dengan kata lain mekarnya nilai-nilai kemanusiaan yang luhur menuju kesempurnaan dan terwujudlah nilainilai yang baik. Pendidikan kemanusiaan bukan merupakan pelajaran terpisah melainkan harus menjadi inti sari dari semua mata pelajaran, kurikulum dan kegiatan ekstra-kurikuler.

Pendidikan itu mengajarkan kepada kita bahasa dan pengetahuan tetapi tidak ada pelajaran tentang bagaimana kita hidup tenang, bahagia atau dalam kedamaian di antara kita sendiri maupun dengan orang lain. Oleh karena itu Mahatma Gandhi berujar "Pendidikan tanpa karakter adalah sia-sia" (education without character is useless) bahkan sangat membahayakan. Bahkan beliau menyatakan bahwa pendidikan seharusnya mengarahkan kepada kemanusiaan. Pendidikan haruslah membentuk dan mengembangkan karakter ke arah yang lebih baik. Pendeknya pendidikan seutuhnya harus manusiawi, tidak hanya menyangkut pendidikan intelek tetapi juga kehalusan budi dan disiplin batin.

Dalam Niti Sataka (16) karya Raja Bhartrihari menyebutkan :

Vidya nama narasya rupamadhikam pracchannaguptam dhanam Vidya bhagakari yasah sukhakari vidya gurunam guruh Vidya bondhuiana videsogamone vidya para devata

Vidya rajasu pujyate na hi

dhonom vidyavihinah pasuh

Pengetahuan adalah kecantikan manusia yang paling agung dan merupakan harta yang tersembunyi. Ia adalah sumber dari semua kesenangan, kemasyuran dan kebahagiaan. la adalah guru dari semua guru yang menjadi sahabat di negeri asing. Pengetahuan bagaikan dewa yang dapat mengabulkan setiap 
keinginan. Pengetahuanlah yang dihormati dalam pemerintahan, bukan kekayaan. Oleh karena itu, manusia tanpa pengetahuan yang benar bagaikan binatang.

Artinya, pendidikan memegang kunci yang paling utama dalam hidup. Oleh karena itu Veda menjelaskan bahwa kelahiran dari seorang ibu masih dianggap lebih rendah (ekajati) dengan ketika ia dilahirkan dari pengetahuan melalui guru. Manusia dianggap persis seperti binatang ketika ia tidak memiliki pengetahuan.

Pendidikan secara implisit mengandung tigaelemen dasar sebagai bentuk keseimbangan rohani dan jiwa, yaitu : intelektual, Estetika dan Etika. Intelektual tidak hanya diartikan sebagai bentuk kecerdasan, tetapi secara eksplisit berisikan nilai moral dan karakter. Apabila anak cerdas (intelek) namun tidak hormat kepada orang tua, tidak patuh kepada peraturan sekolah dan gurunya atau orang lain maka ia tidak disebut orang berpendidikan. Bisa saja seorang anak memiliki nilai estetika yang luar biasa, namun kalau dibelikan motor baru lalu dipreteli, corat coret di tembok rumah orang, merusak lingkungan atau pepohonan maka ia tidak termasuk anak cerdas. Ketiga nilai ini harus berkolerasi dan terindepedensi satu sama lain. Anak seperti ini harus diberikan media, kontrol, pemahaman, tuntunan untuk mengekspresikan kreativitasnya. Pendidikan tidak hanya mengasah kecerdasan intelektual yang dikembangkannya bila seseorang dalam tindakannya ternyata membunuh, berkelahi, memperkosa, menipu, korupsi, serta menyalahgunakan kekuasaannya .

\section{B. Pengertian Agama Hindu}

Agama sebagai pengetahuan kerohanian yang menyangkutsoal-soal rohaniyangbersifat gaib dan sangat private. Secara ethimologinya Agama berasal dari bahasa Sansekerta, yaitu dari kata " $a$ " dan "gam". "A" berarti tidak dan "gam" berarti pergi atau bergerak. Jadi kata agama berarti sesuatu yang tidak pergi atau bergerak dan bersifat langgeng. Menurut Hindu yang dimaksudkan memiliki sifat langgeng (kekal, abadi, dan tidak berubahubah) hanyalah Hyang Widhi Wasa (Tuhan Yang Maha Esa). Demikian pula ajaran-ajaran yang diwahyukan-Nya adalah kebenaran abadi yang berlaku selalu, dimana saja dan kapan saja. Berangkat dari pengertian itulah, maka agama adalah merupakan kebenaran abadi yang mencakup seluruh jalan kehidupan manusia yang diwahyukan oleh Hyang Widhi Wasa melalui para Maha Rsi dengan tujuan untuk menuntun manusia dalam mencapai kesempurnaan hidup yang berupa kebahagiaan yang maha tinggi dan kesucian lahir dan bathin.

Keberadaan agama-agama yang ada di dunia ini pada umumnya didasarkan pada pewahyuan Tuhan Yang Maha Esa yang diterima oleh para pendirinya. Sebutan/ nama dari suatu agama biasanya memiliki hubungan yang sangat erat sekali dengan para pendirinya. Sebut saja agama Buddha yang berkaitan erat dengan Sidharta Gautama. Kristen dengan Yesus Kristus. Berbeda dengan agama-agama tersebut, agama Hindu tidak memiliki keterkaitan dengan seorang Maharsi penerima wahyu sebagai pendirinya, karena dalam agama Hindu Wahyu Tuhan Yang Maha Esa itu diterima oleh banyak Maharsi. Para tokoh mengatakan bahwa sebutan Hindu itu berasal dari kata Sindhu yaitu nama sebuah sungai diwilayah india bagian Barat Daya yang sekarang dikenal dengan nama Punjab (daerah 5 aliran sungai).

Dari sekian paparan di atas, maka dapat disimpulkan bahwa pendidikan Agama Hindu adalah suatu proses seseorang untuk mendapatkan pengetahuan, pemahaman dan ketrampilan serta mengembangkan kepribadian (sikap, sifat dan mental) yang berpedoman pada ajaran agama Hindu (Veda). Melalui pendidikan agama Hindu diharapkan para siswa mampu mengetahui dan memahami esensi dari ajaran Agama Hindu itu sendiri

Peran Pendidikan Agama Hindu 
serta mampu mengaplikasikannya ke dalam sebuah kepribadian yang utuh dan bersifat positif.

\section{Tujuan Pendidikan Agama Hindu}

Arah dan tujuan pendidikan adalah mentransformasi nilai-nilai pendidikan agar anak didik memiliki kepribadian yang seutuhnya. Komitmen pendidikan pada dasarnya membawa anak agar menyadari akan kesejatian dirinya (self realizing). Apa yang dikatakan sebagai pendidikan dewasa ini adalah apa yang masih tertinggal pada diri kita setelah semuanya terlupakan. Jadi apa yang masih tertinggal setelah semuanya terlupakan? Watak yang baik. Tanpa watak atau budi pekerti yang baik, pendidikan tidak ada gunanya (Vishvanath, 1997:5).

Pembentukan karakter yang baik pada anak didik sebagaimana Bhagawan Sri Sathya Sai Baba (2000:5) menyatakan :

Tujuan pengetahuan adalah
kearifan
Tujuan peradaban adalah
kesempurnaan
Tujuan kebijaksanaan adalah
kebebasan dan
Tujuan pendidikan adalah
karakter yang baik

Nampaknya, paradigma pendidikan mulai bergeser dari arah untuk membentuk watak yang baik menuju pendidikan yang mengembangkan kecerdasan intelektual. Akhirnya, institusi pendidikan menjadi pasar yang cepat mendatangkan finansial yang berlimpah. Alasannya, institusi pendidikan hanya terjamah dan dinikmati oleh mereka yang mampu untuk membayar mahalnya biaya pendidikan. Institusi pendidikan menimbulkan gap yang tajam karena lembaga ini hanya dapat diakses oleh kalangan yang mampu untuk itu, timbullah ketidakadilan. Tanpa materi dan penggunaan hightech bisa jadi para calon akademisi akan berpaling kepada lembaga pendidikan yang menyediakan fasilitas pendidikan yang lebih canggih, modern dan bermutu sebagaimana yang dibutuhkan. Ada parameter yang substansial dalam dunia pendidikan. Semakin tinggi fasilitas teknologi yang ditawarkan semakin besar biaya pendidikan yang diajukan. Semakin besar biaya pendidikan yang diajukan semakin banyak animo masyarakat yang menyerbu model pendidikan seperti itu. Besarnya animo masyarakat terhadap pendidikan dengan higntech seperti ini, menunjukkan tingkat keberhasilan asumsi dunia pendidikan mengeruk keuntungan. Sepertinya memang dunia pendidikan mahal serta tidak bisa dipisahkan dengan dunia glamor. Agar mencapai 'harga jual' yang mahal dan tidak merendahkan 'gengsi' pendidikan haruslah dunia pendidikan itu mahal dibarengi dengan penyediaan fasilitas yang canggih. Tanpa demikian hampir dipastikan dunia pendidikan akan tertinggal karena tuntutan prigprarisme.

Management Sekolah unggulan pada umumnya menyediakan fasilitas yang lebih lengkap dan canggih. Rasa gengsi, kehormatan, kontinuitas dalam mempertahankan harga diri adalah sebuah keharusan. Walaupun, sangat diabaikan dalam pendidikan formal dalam pemenuhan dunia rohani yang melibatkan nilai moralitas, etika dan karakter, Dalam dunia kerohanian mencari kemashyuran termasuk penghalang kehancuran spiritual. Bahkan setelah melepaskan posisi-posisi keduniawian, keinginan untuk mendapatkan nama besar tetap berada dalam bawah sadar. Oleh karena itu pencari kebenaran hendaknya mengabaikan seluruh tubuh, pikiran, dan jiwanva di konsentrasi kan kepada Tuhan dan tidak memiliki keinginan yang sifatnya diri sendiri. Tujuan Agama Hindu sesungguhnya terkandung dalam ajaran Catur Purusa Artha yaitu empat tujuan hidup umat Hindu. Antara lain Dharma, Artha, Kama dan Moksa. Untuk mencapai artha dan kama maka hendaknya dharmalah yang dicari terlebih dahulu sebagai landasan untuk meraih artha dan kama. Setelah semua itu tercapai barulah menapaki 
ke jenjang Wanaprastha untuk melepaskan diri dari ikatan duniawi dan akhirnya mencapai tujuan akhir yaitu moksartham jagadhita ya ca iti dharma.

Tujuan pendidikan agama Hindu telah dirumuskan oleh Parisada Hindu Dharma Indonesia Pusat melalui seminar kesatuan tafsir terhadap aspek-aspek agama Hindu sebagai berikut :

1. Menanamkan ajaran agama Hindu menjadi keyakinan dan landasan segenap kegiatan umat Hindu dalam semua perikehidupannya.

2. Ajaran agama Hindu mengarahkan pertumbuhan tata kemasyarakatan umat Hindu hingga serasi dengan Pancasila, dasar negara Republik Indonesia.

3. Menyerasikan dan menyeimbangkan pelaksanaan bagian-bagian ajaran agama Hindu dalam masyarakat antara tatwa, susila dan upacara.

4. Untuk mengembangkan hidup rukun antar umat berbagai agama.

Presiden RI. I, Ir. Soekarno memahami pemikiran Swami Vivekananda bahwa tujuan pendidikan itu adalah pembentukan karakter anak didik atau anak-anak yang suputra seperti diharapkan oleh orang tua, guru, dan masyarakat. Bung Karno juga memahami tentang Tat Twam Asi, Advaita, Vedanta dan sebagainya dan beliau berujar "Saya sangat memahami ucapan Vivekananda" kata Bung Karno. Gurunya Vivekananda namanya Ramakrishna duduk dirumahnya, diserambi muka, sedang hujan. Duduk di dalam rumahnya tidak akan kena air hujan. Dia melihat orang berjalan kehujanan. Ramakrishna yang duduk di dalam rumah menggigil kedinginan. Orang lain yang kena air hujan dia yang kedinginan. Oleh karena itu, Advaita berkata, paham kesatuan berkata : Tat Twam Asi, dia adalah aku, aku adalah dia. Bung Karno kemudian menggagas ide cemerlang dengan mengemukakan pendidikan sebagai "nation and character building".

\section{Peran Pendidikan Agama Hindu dalam Membentuk Kepribadian Siswa}

Inti ajaran agama Hindu terdiri dari bagian yang disebut dengan Tri Kerangka Agama Hindu. Tri Kerangka Agama Hindu itu sendiri dibagi menjadi 3 bagian antara lain :

Tattwa (filsafat)

Susila (etika)

Upacara (ritual)

Dari ketiga kerangka tersebut, dapat dikembangkan menjadi beberapa ajaran agama Hindu yang kemudian diaplikasikan kedalam sebuah praktek upakara atau simbolsimbol yang mencerminkan makna dari ajaran agama tersebut.

Jika diibaratkan tattwa itu adalah kepala, susila adalah hati, upacara adalah tangan dan kaki agama. Dapat juga diandaikan sebagai sebuah telor, sarinya adalah tatwa, putih telornya adalah susila dan kulitnya adalah upacara. Telor ini akan busuk jika satu dari bagian ini tidak sempurna. Maka dari itu, ketiga kerangka ini haruslah seimbang.

Banyak tattwa yang mampu membuat seseorang menjadi berubah kearah yang lebih positif bila saja seseorang itu mampu memaknai tattwa tersebut dan mampu disesuaikan dengan kehidupan yang sekarang. Contoh yang sehari-hari kita dengar yaitu ucapan Om Swastyastu. Andai saja ucapan ini dapat dipahami dan dimaknai oleh seorang siswa, pastinya akan ada suatu anugrah, berkah dan timbulnya aura positif dari ucapan yang sangat dalam tattwanya (filsafatnya). Kata Om merupakan aksara suci untuk Sang Hyang Widhi Wasa, Swastyastu berasal dari bahasa Sansekerta yang artinya semoga selalu berada dalam keadaan yang baik atas karunia Hyang Widhi. Sungguh luar biasa makna dibalik kata yang sederhana di atas. Tapi seakan-akan orang-orang atau khususnya para siswa, hanya sekedar mengucapkannya sebagai salam saja tanpa mengetahui makna dibalik kata-kata tersebut.

Peran Pendidikan Agama Hindu 
Sama halnya dengan mengucapkan mantrammantram suci ketika bersembahyang. Bila diucapkan dengan sungguh pasti akan timbul suatu getaran sehingga persembahyangan tersebut akan terasa sangat hikmat. Dari hal-hal tersebut secara tidak langsung akan mempengaruhi psikologi seseorang dengan adanya keyakinan akan Beliau, pastinya akan muncul pemikiran-pemikiran positif sehingga mampu untuk berbuat yang positif pula. Hal apapun menyangkut tattwa tentang ketuhanan haruslah diajarkan sejak dini kepada si anak. Dan disekolah pun guru-guru harus mampu memberikan pesan-pesan yang menyangkut tentang ajaran agama terutama kepercayaan terhadap Hyang Widhi haruslah ditingkatkan.

Dengan kepercayaan dan kepahaman akan adanya Ida Sang Hyang Widhi Wasa, maka akan timbul pemikiran positif yang akhirnya mampu diterapkan oleh para siswa kedalam sebuah tindakan konkret pastinya tindakan konkret tersebut haruslah bersifat positif. Dalam agama Hindu tingkah laku yang baik disebut dengan susila. Agama merupakan dasar tata susila yang kokoh dan kekal. Ibarat bangunan jika landasan/pondasinya tidak kokoh maka niscaya bangunan tersebut akan mudah roboh. Hal inilah yang harus diresapi oleh semua orang khususnya para siswa sebagai generasi bangsa. Banyak kejadiankejadian yang terjadi akibat dari perbuatan yang melanggar dari ajaran tata susila.

Banyak siswa yang melanggar normanorma sehingga bertindak diluar dari ajaran agama. Misal saja adanya genk motor yang ujung-ujungnya terjadi perkelahian. Adanya tawuran antar pelajar, siswa yang memakai narkoba, memperkosa, membunuh dan yang sering terjadi adalah kasus pencurian dengan berbagai macam alasan. Mengapa siswa tersebut melakukan hal seperti itu? Dari berbagai kejahatan tersebut, tentu dapat dipastikan salah satu faktornya adalah semakin terdegradasinya moral serta etika di dalam diri para siswa.
Disinilah peran pendidikan agama Hindu yang notabene dibagi menjadi 2 yaitu pendidikan formal dan non formal. Pendidikan formal tentu saja didapat dari proses pembelajaran agama Hindu oleh guru. Pendidikan yang dari sekolah tersebut, pada umumnya hanya bersifat teoritis yang dalam mekanisme pembelajarannya adalah menyampaikan pesan moral, budi pekerti, tata susila, dan makna-makna ajaran agama Hindu yang diharapkan mampu mendoktrin pikiran para siswa agar tidak melanggar dari apa yang diajarkan oleh agama Hindu. Contoh, adanya ajaran Tat Twam Asi, Ahimsa yang mengajarkan para siswa untuk memiliki sifat welas asih dan tidak menyakiti atau pun membunuh makhluk lainnya. Diajarkan pula dalam agama Hindu agar para siswa berbuat, berbicara dan berpikir yang baik yang disebut dengan Tri Kaya Parisudha. Banyak ajaran agama Hindu yang seharusnya mampu mendoktrin pemikiran para siswa.

Jikalau pendidikan formal belum mampu untuk mendoktrin pikiran siswa agar tidak menyimpang dari ajaran agama, ada hal lain yang dapat digunakan sebagai penunjang dari pendidikan formal tersebut yaitu pendidikan non formal. Dalam pendidikan ini yang pertama perlu disorot adalah bagaimana caranya suatu keluarga (orang tua) menanamkan ajaran-ajaran agama Hindu kepada anaknya sejak dini.

Bila sejak dini sudah diajarkan, pastinya kita berharap agar ketika anak itu dewasa, akan muncul karakter yang baik. Kegiatankegiatan yang bersifat sosioreligius harusnya mampu untuk membentuk kepribadian siswa agar menjadi lebih baik. Contohnya seperti kegiatan ngayah di Pura. Disamping kita dapat bersosialisasi dengan orang lain, dapat beradaptasi dengan keadaan dan lingkungan, serta dapat pula meningkatkan ketrampilan dalam membuat sarana upakara seperti membuat penjor, tipat, membuat canang, banten dan lain sebagainya. Dengan kegiatan- 
kegiatan positif ini, disamping pembentukan karakter yang baik, tetapi juga mampu untuk mengisi waktu luang siswa agar tidak terisi oleh kegiatan-kegiatan negatif. Disekolah pun harus meningkatkan ekstrakurikuler keagamaan sebut saja Dharma Gita, Dharma Wacana, praktek upakara mejejaitan. Dan sekolah harus membuat program-program yang bersifat sosioreligius. Dengan berbagai hal yang dipersepsikan di atas mengenai ajaran agama Hindu, diharapkan agar mampu membentuk kepribadian yang baik dan mempu mengikis sedikit demi sedikit krisis moral yang terjadi selama ini terutama dikalangan siswa. Karena kembali ke awal tujuan pendidikan adalah disamping cerdas secara intelektual, tapi juga harus membentuk karakter yang positif.

\section{PENUTUP}

Pendidikan Agama Hindu merupakan suatu proses seorang siswa untuk mendapatkan pengetahuan, pemahaman dan ketrampilan serta mengembangan kepribadian (sikap, sifat dan mental) yang berpedoman pada ajaran agama Hindu (Weda). Tujuan pendidikan agama Hindu tercantum dalam Catur Purusa Artha dan juga telah dirumuskan oleh PHDI dan yang paling terpenting adalah pendidikan agama Hindu harus mampu membentuk kepribadian siswa yang baik dan mampu mengikis krisis moral yang dihadapi siswa sekarang ini.

Pendidikan agama Hindu sangat berperan dalam membentuk kepribadian siswa dengan berbagai ajaran Hindu dan praktek-praktek upakara akan mampu membantu proses pembentukan kepribadian yang mengarah ke arah positif

\section{DAFTAR PUSTAKA}

Jalaluddin, Psikologi Agama, PT RajaGrafindo Persada: Jakarta, 2004. cet. Ke-8

Jalaluddin, Psikologi Agama, PT RajaGrafindo Persada: Jakarta, 2004. cet. Ke-8 Prof. Dr. H. Jalaluddin, Psikologi Agama, PT RajaGrafindo Persada: Jakarta, 2004. Cet ke-8. hal. 255-257

Ridwan Aldursanie, Pendidikan Agama Membangun Moral, (http://ridwan202. wordpress.com/, 